\title{
Een verloren generatie van jongeren op de arbeidsmarkt?
}

\author{
Maarten H.J. Wolbers
}

Gedurende de economische crisis in de jaren tachtig van de vorige eeuw deden verhalen de ronde over het ontstaan van een verloren generatie van jongeren op de arbeidsmarkt. Ook nu weer tijdens de huidige crisis. De vraag is of dat gerechtvaardigd is. Daarom wordt in dit artikel onderzocht in hoeverre recente generaties van jongeren (langdurige) hinder ondervinden van een hoge werkloosheid bij intrede op de arbeidsmarkt. Voor het beantwoorden van deze vraag wordt gebruikgemaakt van herhaalde cross-secties van de Enquête Beroepsbevolking (EBB) (1993-2011). Aan de hand van pseudo-panel analyse worden arbeidsmarktcohorten 'gevolgd' tijdens de vroege beroepsloopbaan. De resultaten laten zien dat een arbeidsmarktintrede in tijden van hoge werkloosheid nadelige gevolgen heeft voor de latere kans op werk en het bereikte beroepsniveau. Het negatieve effect van een hoge werkloosheid bij intrede gaat echter weg na een aantal jaren op de arbeidsmarkt. Daarmee is dit negatieve effect niet blijvend, maar verdwijnt het gedurende de vroege beroepsloopbaan. Al met al ondervinden jongeren bij arbeidsmarktintrede dus nadelige gevolgen van een hoge werkloosheid, maar er kan niet worden gesproken van een verloren generatie op de arbeidsmarkt.

Trefwoorden: jeugdwerkloosheid, arbeidsmarktintrede, verloren generatie

\section{Inleiding en probleemstelling}

Sinds de economische crisis van 2008 is de werkloosheid in Nederland sterk toegenomen. Thans bedraagt deze 8,5\% (CBS, 2013). Daarnaast is het aantal WW-uitkeringen flink opgelopen, tot boven de 400 duizend gevallen op dit moment. Ook al trekt de economie voorzichtig weer aan, Nederland moet de komende jaren rekening blijven houden met een hoog werkloosheidscijfer. De verwachte werkgelegenheidsgroei is zo goed als nihil, waardoor het totaal aantal baanopeningen tot 2018 volledig bepaald wordt door de vervangingsvraag. Deze is laag ten opzichte van voorgaande jaren, doordat de doorstroom tussen beroepen stagneert en werknemers tot een hogere leeftijd (moeten) blijven doorwerken (ROA, 2013).

Met het stijgen van de werkloosheid komt er bijna vanzelf veel aandacht voor de arbeidsmarktpositie van jongeren. Dit is niet verwonderlijk, want hun situatie op de arbeidsmarkt reageert over het algemeen heviger en sneller op conjuncturele schommelingen dan die van de totale beroepsbevolking (Borghans \& Wolbers, 2003). In slechte tijden stijgt de jeugdwerkloosheid sneller dan gemiddeld en zodra betere tijden aanbreken, daalt deze vlugger.

Hoewel de werkloosheid onder jongeren de afgelopen jaren flink is gestegen en momenteel zo'n 16\% bedraagt (CBS, 2013), bereikte de jeugdwerkloosheid haar absolute hoogtepunt in Nederland in 1984, met 25\% (Salverda, 2003). Dit was tijdens de vorige grote economische crisis. Er deden toen verhalen de ronde over het ontstaan van een zogenoemde 'verloren'

\footnotetext{
* Maarten Wolbers is werkzaam bij het ITS en de sectie Sociologie van de Radboud Universiteit Nijmegen, e-mailadres: $\underline{m}$.wolbers@its.ru.nl.
} 
generatie van jongeren. Schoolverlaters die de arbeidsmarkt betreden in een situatie van hoge werkloosheid komen moeilijk aan de bak, verliezen hun vaardigheden, worden daardoor minder aantrekkelijk voor werkgevers en gaan verloren voor de arbeidsmarkt (Van Ours, 2009). Ook in de huidige crisis doemt deze vraag weer op. Veelvuldig duikt de term verloren generatie op in de media en wordt deze gebruikt door politici en beleidsmakers om aan te geven hoe ernstig de problemen zijn rondom de arbeidsmarktkansen van de huidige generatie jongeren. "Geen baan en geen vooruitzicht op verbetering", "Jongere werklozen [wereldwijd] die geen carrière kunnen opbouwen of een gezin kunnen stichten", "Hun troosteloze omstandigheden gaan littekens achterlaten". Zo maar wat beginzinnen uit een artikel over de littekens van een verloren generatie zoals dat eind 2013 in het Nederlands Dagblad stond (30 december 2013). Aan het begin van dat jaar stond in de Volkskrant (5 januari 2013) nog een ietwat positiever verhaal waarin werd gesproken van hoop voor verloren generaties. "Het komt wel weer goed", daarbij verwijzend naar de groep jeugdwerklozen uit de jaren tachtig die uiteindelijk goed is terechtgekomen in de samenleving. Mirjam Sterk, ambassadeur jeugdwerkloosheid, is nog een stuk stelliger. Zij zegt in een recent interview in Intermediair (12 december 2013) dat zij niets merkt van een verloren generatie onder jongeren. Maar wat is de empirische houdbaarheid van al deze uitspraken?

Eerdere studies hebben laten zien dat jongeren in Nederland in de jaren tachtig van de vorige eeuw weliswaar een slechte start maakten op de arbeidsmarkt, maar zij wisten deze initiële achterstand (in termen van werkgelegenheidskans en beroepsniveau) tijdens de (vroege) loopbaan goed te maken (Fouarge, 2009; Van Ours, 2009; De Lange et al., 2014a). De Vreyer et al. (2000) vonden voor Nederland daarentegen geen (gemiddeld) effect van een hoge werkloosheid bij intrede op de arbeidsmarkt voor wat betreft de latere kans op werkloosheid. Bij uitsplitsing van de resultaten naar opleidingsniveau observeerden zij echter een interessant resultaat. Een hoge werkloosheid bij intrede heeft een positief effect op de latere werkloosheidskans onder laagopgeleiden, maar een negatief effect onder hoogopgeleiden. Ook Burgess et al. (2003) komen tot een soortgelijke conclusie voor Engeland. Deze auteurs stellen meer in het algemeen dat een hoge werkloosheid bij intrede op de arbeidsmarkt heterogene effecten kan hebben, bijvoorbeeld ook naar geslacht. Daarbij zouden de effecten voor vrouwen groter zijn dan voor mannen. Bovendien is het volgens hen inderdaad de vraag in hoeverre voor individuen de nadelige gevolgen van een periode van werkloosheid aan het begin van de beroepsloopbaan blijvend zijn of niet. Ze beargumenteren dat het heel goed mogelijk is dat het litteken van vroege werkloosheid verdwijnt na verloop van tijd.

Ondanks dat de huidige crisis anders is en de Nederlandse arbeidsmarkt in de tussentijd een stuk flexibeler is geworden, blijt het een interessante vraag of ook meer recente generaties van jongeren (langdurig) hinder ondervinden van een hoge werkloosheid bij hun intrede op de arbeidsmarkt. Op een flexibele arbeidsmarkt kan de werkloosheid weliswaar oplopen, maar er zullen dan relatief snel aanpassingen plaatsvinden in arbeidsrelaties, door werknemers tijdelijk in dienst te nemen en/of een deeltijdaanstelling te geven, of buiten arbeidsrelaties om, door bijvoorbeeld aan zzp'ers opdrachten te verstrekken, waardoor de nadelige gevolgen van werkloosheid wellicht beperkt blijven. Anderzijds ervaren jongeren tegenwoordig veel meer concurrentie op de Nederlandse arbeidsmarkt dan indertijd. Allereerst van hun eigen, nog studerende generatiegenoten, die door de almaar lagere studiebeurzen steeds vaker een bijbaantje zijn gaan nemen. In de jaren tachtig was deze 
situatie anders met het veel ruimere studiebeurzenstelsel. Daarnaast was in de jaren tachtig de arbeidsmarktparticipatie van vrouwen veel lager. Vanaf de jaren negentig kwamen zij massaal de arbeidsmarkt op. Ook staan ouderen meer dan voorheen te dringen. Gunstige (VUT) en minder gunstige (WAO) uittrederoutes voor oudere werknemers zijn verdwenen, waardoor zij langer moeten doorwerken. Eveneens gaat de pensioengerechtigde leeftijd stapsgewijs omhoog. Het blijft al met al gissen of er een recente, verloren generatie van jongeren op de Nederlandse arbeidsmarkt bestaat. Met het beantwoorden van de onderzoeksvragen die in dit artikel centraal staan wordt een bijdrage geleverd aan het oplossen van deze kwestie:

1. Is er een negatief effect van een hoge werkloosheid bij intrede op de latere kans op werk en het bereikte beroepsniveau van individuen die in de periode 1993-2011 de Nederlandse arbeidsmarkt hebben betreden?

2. Is dit negatieve effect blijvend of verdwijnt het na verloop van tijd?

3. Verschilt dit negatieve effect tussen mannen en vrouwen en tussen lager en hoger opgeleiden?

Er wordt op twee manieren vooruitgang geboekt ten opzichte van recent, ander Nederlands onderzoek naar het bestaan van verloren generaties op de arbeidsmarkt. In de eerste plaats heeft deze vordering betrekking op de gevolgde aanpak. Evenals bij Van Ours (2009) en Fouarge (2009) wordt hier gebruikgemaakt van herhaald dwarsdoorsnede-onderzoek op basis van de Enquête Beroepsbevolking (EBB). De analyse van Van Ours is echter zeer beschrijvend van aard en de auteur toetst niet direct het effect van een hoge werkloosheid bij arbeidsmarktintrede op de latere kans op werk. Bovendien is het verschil tussen cohort- en levensloopeffecten niet te ontwarren. De analyse van Fouarge is weliswaar modelmatig opgezet, maar de auteur volgt de onderscheiden cohorten schoolverlaters niet tijdens hun beroepsloopbaan. In plaats daarvan gebruikt hij informatie uit de EBB 2001-2007, reconstrueert hij op basis hiervan intredecohorten en schat vervolgens voor de individuen uit deze cohorten hun arbeidsmarktpositie bij intrede, zonder deze feitelijk waar te nemen. In dit artikel wordt aan al deze nadelen tegemoetgekomen door een pseudo-panel analyse uit te voeren waarbij de loopbanen van cohorten schoolverlaters, die in de periode 1993-2011 de Nederlandse arbeidsmarkt hebben betreden, worden vergeleken.

In de tweede plaats ligt de toegevoegde waarde van dit artikel in het bestuderen van heterogene effecten van een hoge werkloosheid bij arbeidsmarktintrede op de vroege beroepsloopbaan. Verondersteld wordt dat er verschillen zijn tussen groepen van schoolverlaters als het gaat om het effect van een hoge werkloosheid bij intrede. In de analyse worden daarom twee belangrijke individuele kenmerken (sekse en opleidingsniveau) onderscheiden waarlangs ongelijkheden op de arbeidsmarkt tot stand komen. 


\section{Theoretische verwachtingen}

Arbeidsmarktintrede in tijden van hoge werkloosheid is om twee redenen problematisch (Fouarge, 2009). Allereerst is door de hoge werkloosheid de gemiddelde duur bij het vinden van een eerste baan langer. Dit staat de (verdere) opbouw van menselijk kapitaal in de weg (Becker, 1964). Beroepservaring wordt beschouwd als de belangrijkste manier om menselijk kapitaal op te bouwen tijdens de loopbaan. Ze staat voor de hoeveelheid scholing die vereist is om adequaat te kunnen functioneren op de werkvloer. Werkgevers streven ernaar om de scholingskosten van werknemers zo laag mogelijk te houden en daarom vinden zij individuen met beroepservaring aantrekkelijker dan degenen zonder relevante ervaring, omdat eerstgenoemden over meer (beroeps- of bedrijfs)specifieke kennis en vaardigheden beschikken. Het is volgens deze theorie evident dat werkloosheid bij intrede op de arbeidsmarkt de opbouw van menselijk kapitaal ondermijnt, omdat geen werk hebben leidt tot een verlies aan productieve vaardigheden en een gebrek aan beroepservaring.

Daarnaast verlagen schoolverlaters in tijden van hoge werkloosheid hun reserveringsloon (Mortensen, 1977). Na verloop van tijd zullen individuen, wanneer zij nog geen baan op niveau hebben weten te bemachtigen, hun doelen en voorkeuren aanpassen en bereid zijn onder hun niveau te gaan werken in plaats van langer werkloos te blijven. Dit heeft overscholing en verdringing op de arbeidsmarkt tot gevolg (Wolbers, 2011).

De verwachting is echter dat de nadelige gevolgen van een hoge werkloosheid bij arbeidsmarktintrede van beperkte duur zijn (Burgess et al., 2003). Zodra de feitelijke arbeidsproductiviteit van werknemers, afgemeten aan hun beschikbare kennis en vaardigheden, duidelijk wordt, dan kan dit de nadelige gevolgen van werkloosheid bij arbeidsmarktintrede teniet doen. Gardecki en Neumark (1998) vinden empirische steun voor deze stelling. Zij concluderen dat de arbeidsmarktuitkomsten van individuen rond hun dertigste levensjaar grotendeels ongerelateerd zijn aan vroege arbeidsmarktervaringen, vooral bij mannen. Het enige blijvende effect dat kan worden waargenomen is dat jongeren, die aan het begin van hun carrière werkloosheid hebben ervaren, minder werkervaring opbouwen tijdens hun latere loopbaan en om die reden terechtkomen in lagere beroepsposities waar ze minder verdienen (Ellwood, 1982).

Bovendien is het aannemelijk dat er heterogene effecten van een hoge werkloosheid bij arbeidsmarktintrede zijn (Burgess et al., 2003; zie ook Wolbers, 2010). Het is goed mogelijk dat sommige individuen relatief weinig last ondervinden van een hoge werkloosheid bij intrede, terwijl voor anderen de nadelige gevolgen hiervan voor de latere beroepsloopbaan veel groter zijn. Vooral vanuit de arbeidsmarktsegmentatietheorie valt dit te begrijpen. Volgens deze theorie kan de arbeidsmarkt worden opgedeeld in twee segmenten: de primaire en de secundaire arbeidsmarkt (Piore, 1975). Op de primaire arbeidsmarkt bevinden zich vooral werknemers met goedbetaalde, vaste banen en (bedrijfsinterne) promotiemogelijkheden. Het gaat hier om de vaste kern van een bedrijf of organisatie die de hoofdactiviteiten uitvoert. Om een plek op de primaire arbeidsmarkt te bemachtigen, zijn veelal beroepsgerichte kennis en vaardigheden (minimaal op het niveau van het middelbaar beroepsonderwijs) vereist. Werkgevers gebruiken opleiding daarbij als een 'screening device' om de vaardigheden van potentiële werknemers in te schatten en zij baseren zich daarop bij hun aannamebeleid. Op de secundaire arbeidsmarkt gaat het daarentegen met name om werknemers met een tijdelijk dienstverband, zoals uitzendkrachten. Werkgevers maken gebruik van deze externe arbeidskrachten om fluctuaties in de te verrichten arbeid op te vangen. Zodra de productie van het bedrijf inzakt, zijn deze tijdelijke arbeidskrachten overbodig en worden zij ontslagen. Werkgevers zijn dan ook niet geneigd om (veel) te 
investeren in deze werknemers. Het betreft vaak ondersteunende en tijdelijke werkzaamheden, die weinig formele scholing vereisen. Dit impliceert dat opleiding een tamelijk irrelevant selectiecriterium is voor werkgevers op de secundaire arbeidsmarkt. In plaats daarvan zijn zij aangewezen op de arbeidsgeschiedenis van individuen, die als een direct signaal voor hun productiviteit geldt. Daarom wordt verondersteld dat de nadelige gevolgen van een hoge werkloosheid bij intrede groter zijn op de secundaire dan op de primaire arbeidsmarkt, gegeven de sterkere nadruk op de individuele 'track record' in het eerstgenoemde segment. Dit wordt waarschijnlijk nog vergroot door het feit dat er amper mobiliteit is tussen beide arbeidsmarktsegmenten, waardoor schoolverlaters die de secundaire arbeidsmarkt hebben betreden, vaak 'gevangen' komen te zitten in hun tijdelijke en marginale positie en als gevolg daarvan nauwelijks enig perspectief hebben op een betere en meer stabiele arbeidsmarktpositie.

In de empirische analyse van dit artikel wordt een indirecte strategie gekozen om beide arbeidsmarktsegmenten te onderscheiden door naar twee specifieke kenmerken van individuen te kijken die grotendeels bepalen of zij in het ene of het andere segment werkzaam zijn. Het eerste kenmerk betreft opleidingsniveau. Zoals hierboven al is aangegeven, veronderstelt de segmentatietheorie dat toegang tot de primaire arbeidsmarkt slechts mogelijk is als individuen beschikken over beroepsgerichte kennis en vaardigheden (minimaal op het niveau van het middelbaar beroepsonderwijs), terwijl het werk op de secundaire arbeidsmarkt vaak ondersteunende en tijdelijke werkzaamheden betreft, die weinig formele scholing vereisen. Op basis hiervan kan worden verwacht dat laagopgeleiden vooral op de secundaire arbeidsmarkt worden aangetroffen. Gegeven de veronderstelling dat werkgevers hier hoofdzakelijk afgaan op de individuele arbeidsgeschiedenis in plaats van kwalificaties om de productiviteit van werknemers in te schatten, kan worden voorspeld dat voor lager opgeleiden de nadelige gevolgen van een hoge werkloosheid bij intrede voor de (vroege) beroepsloopbaan groter zijn dan voor hoger opgeleiden.

Hetzelfde argument kan worden toegepast op verschillen tussen mannen en vrouwen. Vrouwen worden - ongeacht hun opleidingsniveau - vaker op de secundaire arbeidsmarkt aangetroffen dan mannen en daarom zijn de nadelige gevolgen van een hoge werkloosheid bij intrede voor de vroege loopbaan voor vrouwelijke werknemers naar verwachting groter. Daarnaast voorkomen loopbaanonderbrekingen van vrouwen (om te zorgen voor kinderen en het huishouden) de opbouw van hun menselijk kapitaal, wat voor hen de negatieve gevolgen van een hoge werkloosheid bij intrede op de arbeidsmarkt ook groter maken.

\section{Data en methode}

De identificatie van generatie- of cohorteffecten kan niet worden gerealiseerd met crosssectionele data, omdat het hiermee onmogelijk is deze te onderscheiden van levensloopeffecten. Paneldata verschaffen de ideale informatie om zo'n analyse uit te voeren. Deze data zijn echter schaars, kennen vaak een relatief korte tijdsspanne en de uitval is hoog. Een alternatief is het gebruik van herhaalde cross-secties om daarmee een pseudo-panel te creëren door individuele observaties te groeperen binnen cohorten gebaseerd op een combinatie van tijdsonafhankelijke kenmerken (Deaton, 1985). In dit artikel wordt een dergelijke pseudo-panel analyse uitgevoerd. Daarbij wordt gebruikgemaakt van herhaalde cross-secties van de Enquête Beroepsbevolking (EBB), verzameld in de periode 1993-2011. Een cohort is gedefinieerd als een groep van individuen die in hetzelfde 
jaar het onderwijs hebben verlaten, van hetzelfde geslacht zijn en over hetzelfde opleidingsniveau beschikken. De veronderstelling daarbij is dat individuen, zodra zij het onderwijs hebben verlaten en de arbeidsmarkt hebben betreden, niet meer terugkeren in de schoolbanken zodat hun opleidingsniveau hetzelfde blijt gedurende de beroepsloopbaan. Op deze manier is de combinatie van het jaar van schoolverlaten ${ }^{1}$, geslacht en opleidingsniveau tijdsonafhankelijk en kan deze worden gebruikt om zogenoemde arbeidsmarktcohorten te definiëren. ${ }^{2}$ Er zijn dus net zoveel arbeidsmarktcohorten als combinaties van deze drie kenmerken. Door verschillende, opeenvolgende jaargangen van de EBB te vergelijken, worden arbeidsmarktcohorten als het ware 'gevolgd' tijdens de vroege beroepsloopbaan (het oudste cohort 18 jaar [1993-2011] en het jongste nul jaar [alleen in 2011], en gemiddeld zo'n negen jaar). De veronderstelling daarbij is dat de individuele variatie binnen cohorten random is en de cohortgemiddelden kunnen worden opgevat als consistente schattingen van de niet-geobserveerde cohortgemiddelden in de populatie. Dit laatste is des te meer het geval, naarmate het aantal individuen binnen de onderscheiden arbeidsmarktcohorten groter is. In deze analyse worden 1.900 arbeidsmarktcohort*jaar combinaties $^{3}$ van gemiddeld 159 respondenten onderscheiden, wat een voldoende groot aantal is voor betrouwbare schattingen. Om rekening te houden met verschillen in de steekproefomvang tussen de arbeidsmarktcohort*jaar combinaties (en daarmee met verschillen in de betrouwbaarheid tussen cohortgemiddelden) zijn deze gewogen naar hun omvang.

Het cohorteffect is in eerste instantie gemodelleerd door het jaar van intrede (als dummyvariabelen) in de analyse op te nemen. Een mogelijk levensloopeffect is vastgesteld via de variabele arbeidsmarktervaring (en het kwadraat ervan). Omdat het cohorteffect voor een deel ook een periode-effect oppikt, zijn de cohortdummies in tweede instantie vervangen door een meting van het werkloosheidspercentage in het jaar van intrede. Het betreft hier het werkloosheidspercentage van de totale beroepsbevolking. Het periode-effect is bepaald als het huidige werkloosheidspercentage. ${ }^{4}$

In figuur 1 is weergegeven hoe dit werkloosheidspercentage zich heeft ontwikkeld in de periode 1993-2011. Eveneens zijn ontwikkelingen in jeugdwerkloosheid gepresenteerd. Duidelijk is het cyclische patroon in de werkloosheid te herkennen. Verder is te zien dat de werkloosheid onder jongeren hoger is dan onder de totale beroepsbevolking en wat sneller stijgt en daalt naar gelang de stand van de conjunctuur.

[Figuur 1]

De kans op werk op het moment van ondervraging is de eerste afhankelijke variabele die wordt geanalyseerd. Deze kans is met een factor 100 vermenigvuldigd zodat de coëfficiënten als percentagepunten kunnen worden geïnterpreteerd. Werkzame personen zijn daarbij afgezet tegen degenen die werkloos of inactief zijn. De tweede afhankelijke variabele betreft het bereikte beroepsniveau van individuen. Dit is vastgesteld aan de hand van de $1^{\text {ste }}$ digit van de Standaard Beroepenclassificatie (SBC) van het CBS, die varieert van 1 (elementaire beroepen) tot en met 5 (wetenschappelijke beroepen). 


\section{Resultaten}

Model 1 van tabel 1 laat allereerst zien dat de kans op werk voor hoger opgeleiden groter is dan voor lager opgeleiden. Daarnaast is gevonden dat vrouwen een kleinere kans op werk hebben dan mannen. Verder komt naar voren dat de invloed van arbeidsmarktervaring op de kans op werk positief is, maar het voordeel ervan neemt af gedurende de loopbaan. Het effect van het jaar van intrede, tot slot, toont dat de kans op werk sterk afhangt van de stand van de conjunctuur. Vooral opvallend is de sterke teruggang in de kans op werk sinds het begin van de economische crisis in 2008. Jongeren die de arbeidsmarkt hebben betreden in 2010 of 2011 zijn verreweg het slechtst af.

Model 2 bevestigt deze laatste bevindingen. Gevonden is dat de kans op werk lager is wanneer het werkloosheidspercentage bij intrede op de arbeidsmarkt hoger is. Dit is in overeenstemming met de theoretische verwachting. De geschatte regressiecoëfficiënt bedraagt $-0,750$. Dit houdt in dat de kans op werk met driekwart procent afneemt bij iedere procent stijging van het algemene werkloosheidspeil.

Voor een deel hangt dit cohorteffect samen met een periode-effect (zie model 3). Wanneer rekening wordt gehouden met het werkloosheidspercentage op het moment van ondervraging, dan is het effect van het werkloosheidspercentage bij intrede gereduceerd tot 0,318 . Bovendien blijkt uit dit model dat de invloed van het huidige werkloosheidspercentage veel groter is: $-1,911$. Dit houdt in dat de huidige conjuncturele omstandigheden meer bepalend zijn voor de kans op werk dan die bij intrede op de arbeidsmarkt.

Model 4, ten slotte, laat zien dat de invloed van het werkloosheidspercentage bij intrede op de arbeidsmarkt na verloop van tijd wegebt. Bij intrede bedraagt het -0,927; na ruim acht jaar arbeidsmarktervaring is het volledig verdwenen $(0,927 / 0,113=8,204)$. Ook deze bevinding komt overeen met de opgestelde verwachting.

\section{[Tabel 1]}

Tabel 2 laat soortgelijke modellen zien als tabel 1, maar dan met het beroepsniveau als afhankelijke variabele. Model 1 toont ten eerste zien dat hoger opgeleiden in banen met een hoger beroepsniveau terechtkomen dan lager opgeleiden. Ten tweede komt naar voren dat vrouwen gemiddeld genomen een hoger beroepsniveau dan mannen hebben aan het begin van de beroepsloopbaan. Ten derde is te zien dat het bereikte beroepsniveau toeneemt over de beroepsloopbaan. Het effect van arbeidsmarktervaring is immers positief. Wel is het zo dat de meerwaarde van een jaar extra ervaring afneemt tijdens de loopbaan. Ten vierde blijken er wat verschillen in het bereikte beroepsniveau te zijn tussen de jaren. Op het oog lijkt het geobserveerde patroon niet samen te hangen met de conjunctuur.

Toch blijkt dit volgens model 2 wel het geval te zijn. Dit model toont immers dat, zoals verwacht, het werkloosheidspercentage bij intrede een negatief effect heeft op het bereikte beroepsniveau. Individuen die in tijden van hoge werkloosheid de arbeidsmarkt betreden, bereiken door de bank genomen een lager beroepsniveau dan degenen die in een periode van lage werkloosheid intreden op de arbeidsmarkt.

Dit effect is met een kwart gereduceerd als rekening wordt gehouden met de invloed van het huidige werkloosheidspercentage (zie model 3). Eveneens is te zien dat het effect van het huidige werkloosheidspercentage, net als bij de kans op werk, een stuk groter is dan dat van het werkloosheidspercentage bij intrede op de arbeidsmarkt. 
In model 4 is te zien dat het effect van het werkloosheidspercentage bij intrede na bijna 13 jaar is verdwenen. Een hoge werkloosheid bij intrede blijft jongeren dus niet zeer langdurig achtervolgen op de arbeidsmarkt. Deze bevinding bevestigt de theoretische verwachting.

[Tabel 2]

In figuur 2 (zie de tabellen A1 en A2 van de Appendix voor de volledige schattingsresultaten) zijn voor de kans op werk de bevindingen voor mannen en vrouwen (linkerdeel) en lager en hoger opgeleiden (rechterdeel) afzonderlijk weergegeven. Voor wat betreft sekseverschillen geldt dat, zoals verwacht, het effect van een hoge werkloosheid bij intrede op de arbeidsmarkt voor de latere kans op werk voor vrouwen groter is dan voor mannen. Bovendien is het effect voor vrouwen langduriger. Na bijna 12 jaar is het uitgedoofd, terwijl dit voor mannen al binnen zes jaar het geval is. Verschillen naar opleidingsniveau zijn eveneens aanwezig. De invloed van het werkloosheidspercentage bij arbeidsmarktintrede op werkzaamheid is beduidend groter onder hoger (hbo en wo) dan lager (maximaal mbo) opgeleiden. Deze verrassende bevinding strookt niet met de opgestelde verwachting. Voor hoger opgeleiden is het effect na zo'n 10 jaar arbeidsmarktervaring uitgewerkt; voor lager opgeleiden is dit na zes jaar het geval.

[Figuur 2]

Figuur 3 (zie ook de tabellen A3 en A4) toont overeenkomstige cijfers, maar dan voor het bereikte beroepsniveau. Opnieuw is gevonden dat het effect van een hoge werkloosheid bij intrede op de arbeidsmarkt voor vrouwen groter is (ruim vier keer) en langzamer verdwijnt (het verschil is zo'n drie jaar) dan voor mannen. Voor wat betreft verschillen naar opleidingsniveau komt naar voren dat hoger opgeleiden aanmerkelijk meer en langer last hebben van een hoge werkloosheid bij arbeidsmarktintrede dan lager opgeleiden.

[Figuur 3]

\section{Conclusie}

De resultaten van dit artikel hebben laten zien dat een arbeidsmarktintrede in tijden van hoge werkloosheid nadelige gevolgen heeft voor de latere kans op werk en het bereikte beroepsniveau. Het negatieve effect van een hoge werkloosheid bij intrede gaat echter weg na enkele jaren op de arbeidsmarkt. Voor wat betreft de latere kans op werk, is de invloed van een hoge werkloosheid bij intrede na zo'n acht jaar arbeidsmarktervaring verdwenen. Ten aanzien van het bereikte beroepsniveau geldt dat deze invloed na bijna 13 jaar is uitgedoofd. Daarmee zijn de nadelige gevolgen van een hoge werkloosheid bij intrede op de arbeidsmarkt niet blijvend, maar verdwijnen deze gedurende de vroege beroepsloopbaan. Al 
met al ondervinden jongeren bij arbeidsmarktintrede dus nadelige gevolgen van een hoge werkloosheid, maar er kan niet worden gesproken van een verloren generatie op de arbeidsmarkt. $^{5}$

Afzonderlijke analyse van mannen en vrouwen en lager en hoger opgeleiden heeft aan het licht gebracht dat het waargenomen negatieve effect van een hoge werkloosheid bij arbeidsmarktintrede sterker bij vrouwen en hoger opgeleiden optreedt en langzamer bij deze groepen verdwijnt. De constatering dat dit effect bij hoger opgeleiden groter is dan bij lager opgeleiden, is tegen de verwachting in en is in tegenspraak met eerdere bevindingen voor Nederland (De Vreyer et al., 2000). Een mogelijke verklaring voor dit gevonden resultaat is dat door de ver voortgeschreden onderwijsexpansie tegenwoordig vooral de hoger opgeleiden moeite hebben met het vinden van werk (op hun eigen niveau), terwijl dit eerder met name lager opgeleiden parten speelde (Tolsma \& Wolbers, 2010). Hierdoor kan het zijn dat de nadelige gevolgen van een hoge werkloosheid bij intrede nu voor hoger opgeleiden sterker en langduriger zijn dan voor lager opgeleiden.

Betekenen al deze bevindingen dat er helemaal geen beleid nodig is om iets te doen aan de onzekerheid die jongeren op de huidige arbeidsmarkt ervaren? Dit is allerminst het geval. Scholing, werkervaringsprojecten en startersbeurzen zijn wel degelijk zinvol om de afstand van jongeren tot de arbeidsmarkt te verkleinen, ook al is de effectiviteit van dit soort actief arbeidsmarktbeleid soms beperkt. Maar er zal daarnaast beleid op andere terreinen nodig zijn. Gezien het feit dat een hoge werkloosheid jongeren parten speelt bij gezinsvorming (De Lange et al., 2014b), is het wenselijk dat zij ook daar steun kunnen verwachten voor hun onzekere arbeidsmarktpositie. Zo zou de kinderbijslag voor jonge ouders, die werkloos zijn of tijdelijk werk hebben, kunnen worden verhoogd. Of bij tijdelijk werk of een baan onder hun niveau zouden jongeren gemakkelijker een hypotheek (met garantie) moeten kunnen krijgen. Daarvoor zijn afspraken met de overheid en de banken nodig. Dat is lastig, omdat het deels gaat om private partijen. Maar arbeidsmarktonzekerheid enerzijds en economische en sociale onafhankelijkheid anderzijds dienen met elkaar in balans te zijn.

\section{Noten}

1. Het jaar van schoolverlaten is niet exact bekend in de EBB. Deze is benaderd door bij het geboortejaar de gemiddelde leeftijd waarop individuen het onderwijs verlaten op te tellen. Deze leeftijd verschilt per opleiding en is empirisch bepaald op basis van de data zelf. Er zit immers een variabele in de databestanden van de EBB die aangeeft of een respondent het afgelopen jaar het onderwijs heeft verlaten (dat wil zeggen schoolverlater is). De gemiddelde leeftijd bij schoolverlaten is als volgt: lo 17 jaar, lbo en mavo 18 jaar, havo/vwo 20 jaar, mbo 21 jaar, hbo 24 jaar en wo 25 jaar.

2. Het zou uitermate interessant zijn hier ook etnische herkomst te onderscheiden, maar het is vanwege kleine aantallen allochtone respondenten niet goed mogelijk deze variabele als aanvullend kenmerk bij de definiëring van arbeidsmarktcohorten te betrekken.

3. Per meetjaar zijn er 5 opleidingsniveaus (lo, lbo/mavo, havo/vwo/mbo, hbo, wo) ${ }^{*} 2$ geslachten (man, vrouw) * 19 jaren van schoolverlaten $(1993-2011)=190$ arbeidsmarktcohorten onderscheiden. Het arbeidsmarktcohort 1993 is 19 keer geobserveerd (1993-2011), het arbeidsmarktcohort 199418 keer (1994-2011), et cetera. Het arbeidsmarktcohort 2011, ten slotte, is alleen in dit jaar geobserveerd. Het totaal aantal te analyseren arbeidsmarktcohort ${ }^{*}$ jaar combinaties komt daarmee op 
1.900. Een verdere uitsplitsing naar opleidingsniveau was op basis van de data niet goed mogelijk. Dit betekent bijvoorbeeld dat jongeren die havo, vwo of mbo hebben verlaten, als één (heterogene) groep worden gezien. Ook het onderscheid binnen mbo (naar leerweg en niveau) kan helaas niet worden gemaakt, ook al verschilt het arbeidsmarktperspectief tussen deze opleidingen aanzienlijk.

4. Het huidige werkloosheidspercentage is wel gecorreleerd, maar zeker niet een op een gerelateerd aan de afhankelijke variabele kans op werk. Allereerst heeft het huidige werkloosheidspercentage betrekking op de totale beroepsbevolking en betreft de geanalyseerde afhankelijke variabele alleen schoolverlaters. Daarnaast bevat de variabele kans op werk ook alle inactieven (in de referentiecategorie; naast de werklozen), terwijl het werkloosheidspercentage alleen betrekking heeft op de actieve beroepsbevolking.

5. Modelmatig gezien klopt deze conclusie. Immers, na een aantal jaren ervaring op de arbeidsmarkt is het zo dat individuen die in tijden van hoge werkloosheid de arbeidsmarkt hebben betreden een even grote kans op werk hebben of een even hoog beroepsniveau kennen dan degenen die in tijden van lage werkloosheid de arbeidsmarkt hebben betreden. Dit betekent echter niet dat zij daarmee hun opgelopen initiële achterstand (met name in termen van inkomen) hebben weten te compenseren. De gederfde inkomsten aan het begin van de loopbaan (door het ontbreken van werk of door het uitoefenen van een beroep van een lager niveau en navenant salaris) houdt ze - vanuit een levensloopperspectief - blijvend op achterstand, met alle gevolgen (voor gezinsvorming, het kopen van een huis en pensioenopbouw) van dien.

\section{Literatuur}

Becker, G. (1964). Human capital. A theoretical and empirical analysis, with a special reference to education. New York: National Bureau of Economic Research.

Borghans, L. \& Wolbers, M.H.J. (2003). Schoolverlaters in moeilijke tijden. Economisch Statistische Berichten, 88, 212-214.

Burgess, S., Propper, C., Rees, H. \& Shearer, A. (2003). The class of 1981: The effects of early career unemployment on subsequent unemployment experiences. Labour Economics, 10, 291-309.

CBS (2013). Werkloosheid gedaald. CBS Persbericht PB013-72, 21 november 2013. Den Haag: Centraal Bureau voor de Statistiek.

Deaton, A. (1985). Panel-data from times series of cross-sections. Journal of Econometrics, 30, 109-126.

De Vreyer, Ph., Layte, R., Wolbers, M. H. J. \& Hussain, M. (2000). The permanent effects of labour market entry in times of high unemployment. In D. Gallie \& S. Paugam (red.), Welfare regimes and the experience of unemployment in Europe (pp. 134-152). Oxford: Oxford University Press.

Ellwood, D. (1982). Teenage unemployment: Permanent scars or temporary blemishes? In Freeman, R. \& Wise, D. (red.), The youth labor market problem: Its nature, causes and consequences (pp. 349-385). Chicago: Chicago University Press.

Fouarge, D. (2009). Effecten van crisis voor schoolverlaters. Economisch Statistische Berichten, 94, 554-556. 
Gardecki, R. \& Neumark, D. (1998). Order from chaos? The effects of early labor market experiences on adult labor market outcomes. Industrial and Labor Relations Review, 51, 299-322.

Lange, M. de, Gesthuizen, M. \& Wolbers, M.H.J. (2014a). Consequences of a flexible labour market entry for early career development in the Netherlands. Economic and Industrial Democracy, 35, te verschijnen (sinds 29 mei 2013 online gepubliceerd als DOI: $10.1177 / 0143831 \times 13485878)$.

Lange, M. de, Wolbers, M.H.J., Gesthuizen, M. \& Ultee, W.C. (2014b). The impact of macroand micro-economic uncertainty on family formation in the Netherlands. European Journal of Population, 30, 161-185.

Mortensen, D. (1977). Unemployment insurance and labor supply decisions. Industrial Labor Relations Review, 30, 505-517.

Piore, M. (1975). Notes for a theory of labor market stratification. In R. Edwards, M. Reich \& D. Gordon (red.), Labor Market Segmentation (pp. 125-150). London: Lexington Books.

Ours, J. van (2009). Jeugdwerkloosheid in barre tijden. www.MeJudice.nl, 24 november 2009.

ROA (2013). De arbeidsmarkt naar opleiding en beroep tot 2018. ROA-R-2013/11. Maastricht: Researchcentrum voor Onderwijs en Arbeidsmarkt.

Salverda, W. (2003). Jeugdwerkloosheid revisited: terug naar de jaren tachtig? Tijdschrift voor Arbeidsvraagstukken, 19, 332-349.

Tolsma, J. \& Wolbers, M.H.J. (2010). Onderwijs als nieuwe sociale scheidslijn? De gevolgen van onderwijsexpansie voor sociale mobiliteit, de waarde van diploma's en het relatieve belang van opleiding in Nederland. Tijdschrift voor Sociologie, 31, 239-259.

Wolbers, M.H.J. (2010). Blijvende gevolgen van een gebrekkige start? Tijdschrift voor Arbeidsvraagstukken, 26, 223-239.

Wolbers, M.H.J. (2011). Dynamiek in overscholing en verdringing op de arbeidsmarkt. Tijdschrift voor Arbeidsvraagstukken, 27, 398-413.

\section{Appendix}

[Tabel A1]

[Tabel A2]

[Tabel A3]

[Tabel A4] 


\section{Summary}

\section{A lost generation of youth in the labour market?}

Maarten H.J. Wolbers

After the economic crisis of the 1980s concerns have been raised whether the high youth unemployment during that period produced a 'lost generation' of young people. The same question has been asked recently after the emergence of the currently high youth unemployment. But how justified is this issue? In order to find this out, it is investigated in this article to what extent recent cohorts of young people are (permanently) disadvantaged by high unemployment levels at labour market entry. To address this question, repeated crosssections from the Labour Force Survey (1993-2011) were used and pseudo-panel analysis was applied in order to 'follow' labour market entry cohorts during the early career. The results show that labour market entry in times of high unemployment has negative effects on later employment opportunities and occupational status attainment. However, these negative effects disappear after a few years in the labour market. These findings imply that the negative effects of high unemployment at labour market entry are not permanent, but diminish during the early career. All in all, young people experience negative effects of labour market entry in times of high unemployment, but these effects do not produce a lost generation.

Key words: youth unemployment, labour market entry, lost generation 


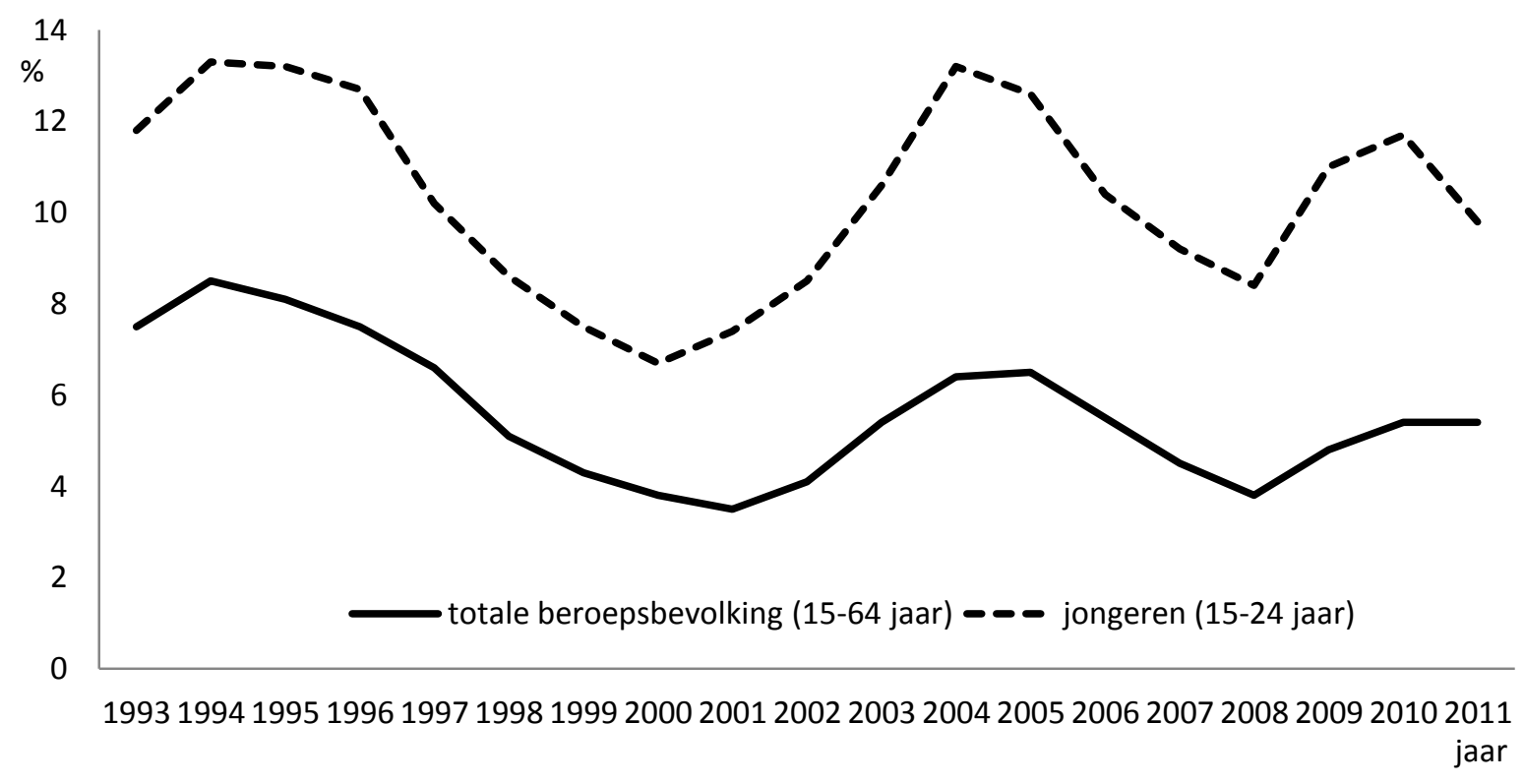

Figuur 1 Ontwikkeling van (jeugd)werkloosheid in de periode 1993-2011

Bron: CBS, Statline 
Tabel 1 Determinanten van de latere kans op werk

\begin{tabular}{|c|c|c|c|c|c|c|c|c|}
\hline \multirow{3}{*}{$\begin{array}{l}\text { Constante } \\
\text { Opleidingsniveau (lo=ref.) }\end{array}$} & \multicolumn{2}{|l|}{ Model 1} & \multicolumn{2}{|l|}{ Model 2} & \multicolumn{2}{|l|}{ Model 3} & \multicolumn{2}{|l|}{ Model 4} \\
\hline & 26,300 & ** & 32,207 & ** & 40,372 & ** & 42,340 & ** \\
\hline & & & & & & & & \\
\hline Lbo/mavo & 15,952 & ** & 15,945 & ** & 16,078 & ** & 16,032 & ** \\
\hline Havo/vwo/mbo & 31,792 & ** & 31,807 & ** & 31,944 & ** & 31,873 & ** \\
\hline $\mathrm{Hbo}$ & 44,688 & ** & 44,720 & ** & 44,845 & ** & 44,788 & ** \\
\hline Wo & 43,949 & ** & 43,995 & ** & 44,170 & ** & 44,105 & ** \\
\hline Vrouw & $-9,772$ & ** & $-9,786$ & ** & $-9,789$ & ** & $-9,790$ & $* *$ \\
\hline Arbeidsmarktervaring & 6,334 & ** & 6,466 & ** & 6,218 & ** & 5,740 & ** \\
\hline $\begin{array}{l}\text { Arbeidsmarktervaring kwadraat } \\
\text { Jaar van intrede (1993=ref.) }\end{array}$ &,- 305 & ** &,- 314 & $* *$ &,- 305 & ** &,- 324 & $\star *$ \\
\hline 1994 &,- 302 & & & & & & & \\
\hline 1995 &,- 098 & & & & & & & \\
\hline 1996 & ,787 & & & & & & & \\
\hline 1997 & 1,448 & & & & & & & \\
\hline 1998 & 1,929 & * & & & & & & \\
\hline 1999 & 2,827 & $* *$ & & & & & & \\
\hline 2000 & 3,073 & ** & & & & & & \\
\hline 2001 & 4,044 & ** & & & & & & \\
\hline 2002 & 3,033 & $* *$ & & & & & & \\
\hline 2003 & 3,606 & ** & & & & & & \\
\hline 2004 & 2,364 & * & & & & & & \\
\hline 2005 & 2,353 & * & & & & & & \\
\hline 2006 & 4,194 & $* *$ & & & & & & \\
\hline 2007 & 4,041 & $* *$ & & & & & & \\
\hline 2008 & 2,888 & * & & & & & & \\
\hline 2009 & ,959 & & & & & & & \\
\hline 2010 & $-3,786$ & * & & & & & & \\
\hline 2011 & $-4,966$ & * & & & & & & \\
\hline Werkloosheidspercentage bij intrede & & &,- 750 & ** &,- 318 & * &,- 927 & ** \\
\hline Werkloosheidspercentage bij intrede*arbeidsmarktervaring & & & & & & &, 113 & ** \\
\hline Huidig werkloosheidspercentage & & & & & $-1,911$ & ** & $-1,656$ & ** \\
\hline Aangepaste $\mathrm{R}$ kwadraat & 841 & & ,839 & & ,849 & & ,850 & \\
\hline
\end{tabular}

${ }^{* *} \mathrm{p}<0,01 ;{ }^{*} \mathrm{p}<0,05 ; \mathrm{N}_{\text {arbeidsmarktcohort }}$ jaar combinaties $=1.900$ en $\mathrm{N}_{\text {individuen }}=302.402$

Bron: EBB 1993-2011, eigen berekeningen 
Tabel 2 Determinanten van het bereikte beroepsniveau

\begin{tabular}{|c|c|c|c|c|c|c|c|c|}
\hline 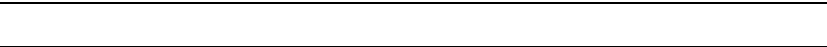 & Model 1 & & Model 2 & & Model 3 & & Model 4 & \\
\hline Constante & 1,673 & $* *$ & 1,739 & ** & 1,811 & ** & 1,830 & ** \\
\hline Opleidingsniveau (lo=ref.) & & & & & & & & \\
\hline Lbo/mavo & ,239 & ** & ,241 & ** & 242 & ** & ,242 & ** \\
\hline Havo/vwo/mbo & ,862 & $* *$ & ,864 & ** & ,866 & ** & ,866 & ** \\
\hline $\mathrm{Hbo}$ & 1,812 & $* *$ & 1,814 & ** & 1,816 & $* *$ & 1,816 & $* *$ \\
\hline Wo & 2,479 & $* *$ & 2,481 & ** & 2,484 & ** & 2,483 & ** \\
\hline Vrouw & ,026 & $* *$ & ,026 & ** & ,026 & ** &, 026 & ** \\
\hline Arbeidsmarktervaring & 043 & ** & ,042 & ** & ,040 & ** & 037 & ** \\
\hline Arbeidsmarktervaring kwadraat &,- 002 & ** &,- 002 & ** &,- 002 & ** &,- 002 & ** \\
\hline Jaar van intrede (1993=ref.) & & & & & & & & \\
\hline 1994 &,- 006 & & & & & & & \\
\hline 1995 &, 000 & & & & & & & \\
\hline 1996 &,- 001 & & & & & & & \\
\hline 1997 &,- 002 & & & & & & & \\
\hline 1998 & 016 & & & & & & & \\
\hline 1999 & ,028 & $* *$ & & & & & & \\
\hline 2000 & 030 & ** & & & & & & \\
\hline 2001 & 028 & * & & & & & & \\
\hline 2002 &, 026 & * & & & & & & \\
\hline 2003 & 020 & & & & & & & \\
\hline 2004 & 042 & $* *$ & & & & & & \\
\hline 2005 & 018 & & & & & & & \\
\hline 2006 & 039 & ** & & & & & & \\
\hline 2007 & 045 & ** & & & & & & \\
\hline 2008 & 056 & ** & & & & & & \\
\hline 2009 & 038 & * & & & & & & \\
\hline 2010 & 047 & * & & & & & & \\
\hline 2011 &,- 016 & & & & & & & \\
\hline Werkloosheidspercentage bij intrede & & &,- 008 & ** &,- 006 & ** &,- 011 & ** \\
\hline Werkloosheidspercentage bij intrede*arbeidsmarktervaring & & & & & & & ,001 & * \\
\hline Huidig werkloosheidspercentage & & & & &,- 016 & ** &,- 014 & ** \\
\hline Aangepaste R kwadraat & ,985 & & ,985 & & ,985 & & ,985 & \\
\hline
\end{tabular}

${ }^{* *} \mathrm{p}<0,01 ;{ }^{*} \mathrm{p}<0,05 ; \mathrm{N}_{\text {arbeidsmarktcohort }{ }^{*} \mathrm{jar} \text { combinaties }}=1.900$ en $\mathrm{N}_{\text {individuen }}=215.308$

Bron: EBB 1993-2011, eigen berekeningen 
arbeidsmarktervaring $\begin{array}{llllllllllllllll}0 & 1 & 2 & 3 & 4 & 5 & 6 & 7 & 8 & 9 & 10 & 11 & 12 & 13 & 14 & 15\end{array}$

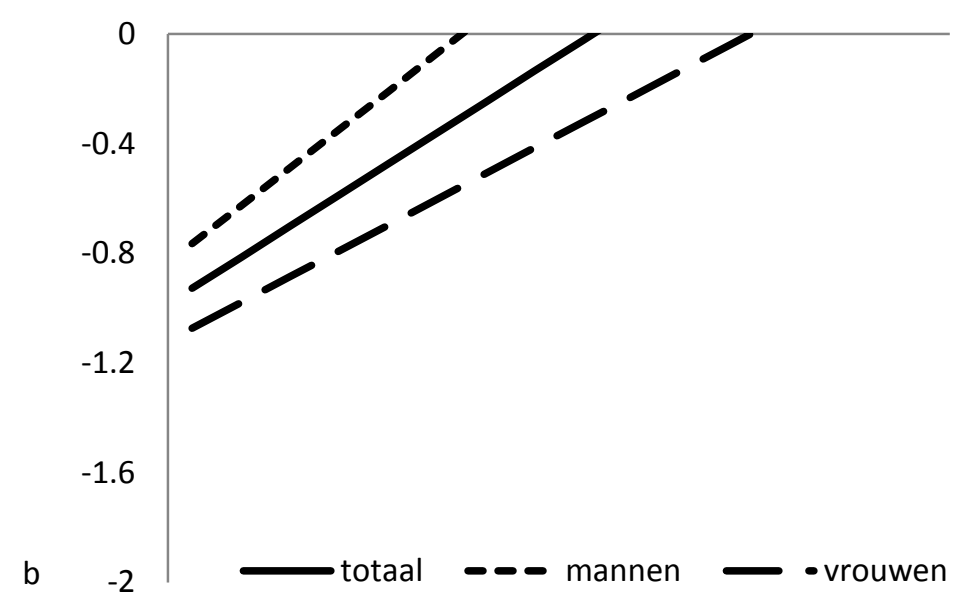

$\begin{array}{llllllllllllllll}0 & 1 & 2 & 3 & 4 & 5 & 6 & 7 & 8 & 9 & 10 & 11 & 12 & 13 & 14 & 15\end{array}$

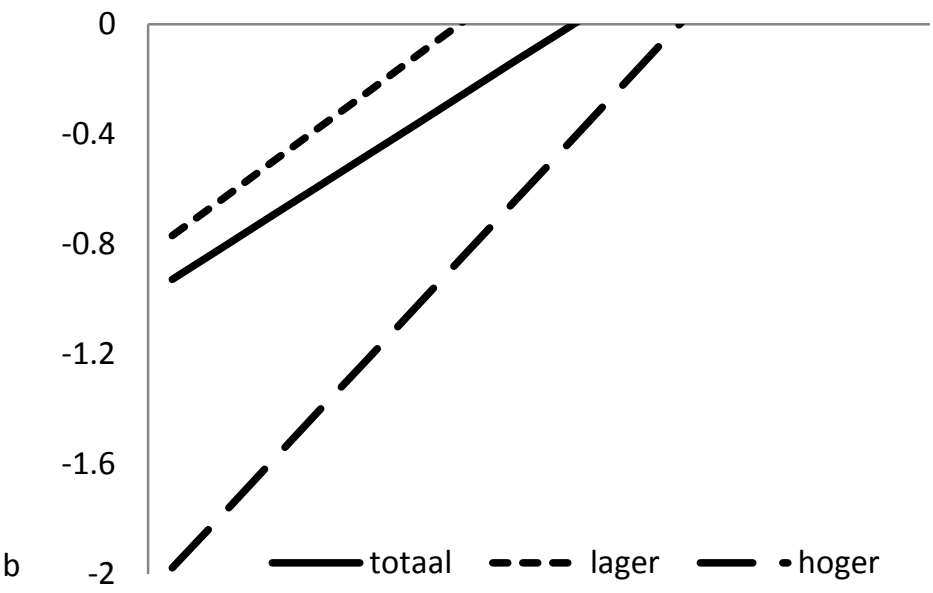

Figuur 2 Effect van werkloosheidspercentage bij intrede op de latere kans op werk naar arbeidsmarktervaring; voor mannen en vrouwen en lager en hoger opgeleiden apart

Bron: EBB 1993-2011, eigen berekeningen 

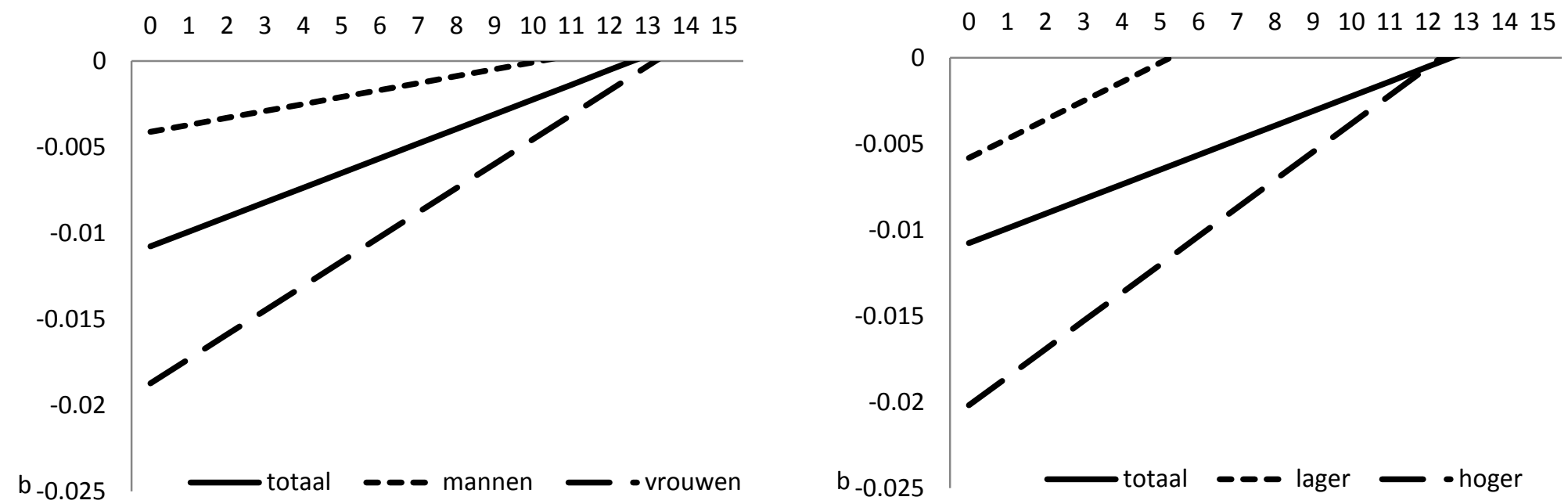

Figuur 3 Effect van werkloosheidspercentage bij intrede op het bereikte beroepsniveau naar arbeidsmarktervaring; voor mannen en vrouwen en lager en hoger opgeleiden apart

Bron: EBB 1993-2011, eigen berekeningen 
Tabel A1 Determinanten van de latere kans op werk; mannen en vrouwen apart

\begin{tabular}{|c|c|c|c|c|c|c|c|c|}
\hline \multirow{2}{*}{$\begin{array}{l}\text { Constante } \\
\end{array}$} & \multicolumn{2}{|c|}{ Model 3: mannen } & \multicolumn{2}{|c|}{ Model 3: vrouwen } & \multicolumn{2}{|c|}{ Model 4: mannen } & \multicolumn{2}{|c|}{ Model 4: vrouwen } \\
\hline & 41,334 & ** & 28,507 & $\star *$ & 43,716 & 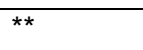 & 30,165 & 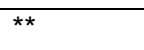 \\
\hline \multicolumn{9}{|l|}{ Opleidingsniveau (lo=ref.) } \\
\hline Lbo/mavo & 14,743 & ** & 17,199 & ** & 14,681 & ** & 17,165 & ** \\
\hline Havo/vwo/mbo & 24,786 & $* *$ & 39,896 & ** & 24,692 & ** & 39,843 & ** \\
\hline Hbo & 34,802 & $* *$ & 54,951 & ** & 34,724 & ** & 54,909 & ** \\
\hline Wo & 34,691 & ** & 54,076 & ** & 34,601 & ** & 54,030 & ** \\
\hline Arbeidsmarktervaring & 7,864 & ** & 4,568 & ** & 7,278 & ** & 4,170 & ** \\
\hline Arbeidsmarktervaring kwadraat &,- 368 & ** &,- 240 & ** &,- 391 & ** &,- 256 & ** \\
\hline Werkloosheidspercentage bij intrede*arbeidsmarktervaring & & & & & 139 & ** & 094 & * \\
\hline Huidig werkloosheidspercentage & $-2,332$ & $* *$ & $-1,496$ & ** & $-2,021$ & ** & $-1,283$ & ** \\
\hline Aangepaste R kwadraat & ,903 & & ,886 & & ,904 & & ,886 & \\
\hline
\end{tabular}

Aangepaste $\mathrm{R}$ kwadraat

886

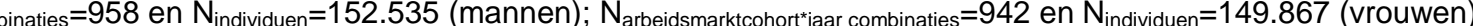
Bron: EBB 1993-2011, eigen berekeningen

Tabel A2 Determinanten van de latere kans op werk; lager en hoger opgeleiden apart

\begin{tabular}{|c|c|c|c|c|c|c|c|c|}
\hline & \multicolumn{2}{|c|}{ Model 3: lager } & \multicolumn{2}{|c|}{ Model 3: hoger } & \multicolumn{2}{|c|}{ Model 4: lager } & \multicolumn{2}{|c|}{ Model 4: hoger } \\
\hline Constante & 58,547 & ** & 96,119 & ** & 60,470 & ** & 100,666 & ** \\
\hline Vrouw & $-10,636$ & ** & $-5,583$ & ** & $-10,624$ & ** & $-5,588$ & ** \\
\hline Arbeidsmarktervaring & 8,368 & ** & 2,491 & ** & 7,808 & ** & 1,690 & ** \\
\hline Arbeidsmarktervaring kwadraat &,- 407 & ** &,- 121 & ** &,- 430 & ** &,- 153 & ** \\
\hline Werkloosheidspercentage bij intrede &,- 101 & &,- 821 & ** &,- 769 & & $-1,977$ & ** \\
\hline Werkloosheidspercentage bij intrede* & & & & & ,131 & * & ,191 & ** \\
\hline Huidig werkloosheidspercentage & $-1,939$ & ** & $-1,478$ & ** & $-1,626$ & ** & $-1,166$ & ** \\
\hline Aangepaste R kwadraat & ,661 & &, 523 & & ,662 & &, 542 & \\
\hline
\end{tabular}

Aangepaste $\mathrm{R}$ kwadrat

, 661

, 523

, 542

opgeleiden)

Bron: EBB 1993-2011, eigen berekeningen 
Tabel A3 Determinanten van het bereikte beroepsniveau; mannen en vrouwen apart

\begin{tabular}{|c|c|c|c|c|c|c|c|c|}
\hline \multirow{2}{*}{ Constante } & \multicolumn{2}{|c|}{ Model 3: mannen } & \multicolumn{2}{|c|}{ Model 3: vrouwen } & \multicolumn{2}{|c|}{ Model 4: mannen } & \multicolumn{2}{|c|}{ Model 4: vrouwen } \\
\hline & 1,797 & ** & 1,814 & $\star *$ & 1,807 & ** & 1,844 & ** \\
\hline \multicolumn{9}{|l|}{ Opleidingsniveau (lo=ref.) } \\
\hline Lbo/mavo & 248 & ** & 248 & ** & 248 & ** & 248 & ** \\
\hline Havo/vwo/mbo & ,802 & $* *$ & ,976 & ** & ,802 & ** & 976 & ** \\
\hline Hbo & 1,780 & $* *$ & 1,895 & ** & 1,780 & ** & 1,895 & ** \\
\hline Wo & 2,439 & ** & 2,572 & ** & 2,439 & ** & 2,571 & ** \\
\hline Arbeidsmarktervaring & ,049 & ** &, 031 & ** &, 048 & ** & ,025 & ** \\
\hline Arbeidsmarktervaring kwadraat &,- 002 & ** &,- 001 & ** &,- 002 & ** &,- 001 & ** \\
\hline Werkloosheidspercentage bij intrede*arbeidsmarktervaring & & & & &, 000 & &, 001 & ** \\
\hline Huidig werkloosheidspercentage &,- 017 & $* *$ &,- 015 & ** &,- 016 & ** &,- 012 & ** \\
\hline Aangepaste R kwadraat & 987 & & ,987 & & ,987 & & 987 & \\
\hline
\end{tabular}

Aangepaste $\mathrm{R}$ kwadraat

987

, 987

aties=1.008 en $\mathrm{N}_{\text {individuen }}=114.233$ (mannen); $\mathrm{N}_{\text {abidsmarktcohort }}$ jaar combinaties $=892$ en $\mathrm{N}_{\text {individuen }}=101.075$ (vrouwen) Bron: EBB 1993-2011, eigen berekeningen

Tabel A4 Determinanten van het bereikte beroepsniveau; lager en hoger opgeleiden apart

\begin{tabular}{|c|c|c|c|c|c|}
\hline & Model 3: lager & Model 3: hoger & Model 4: lager & Model & 4: hoger \\
\hline Constante & $2,287 * *$ & 3,911 ** & 2,309 ** & 3,953 & ** \\
\hline Vrouw & ,105** &,- 014 &, $105 * *$ &,- 014 & \\
\hline Arbeidsmarktervaring &, 064 ** &, $042^{* *}$ & ,059** & 036 & ** \\
\hline Arbeidsmarktervaring kwadraat &,$- 003^{* *}$ &,$- 002 * *$ &,$- 003^{* *}$ &,- 002 & ** \\
\hline Werkloosheidspercentage bij intrede &, 000 &,- 010 &,- 006 &,- 020 & \\
\hline Werkloosheidspercentage bij intrede*arbeidsmarktervaring & & &, 001 & ,002 & \\
\hline Huidig werkloosheidspercentage &,- 008 &,- 016 &,- 006 &,- 013 & \\
\hline Aangepaste R kwadraat & ,183 & ,048 & ,183 & ,047 & \\
\hline
\end{tabular}

Aangepaste $\mathrm{R}$ kwadraat

, 183

, 048

, 047

opgeleiden)

Bron: EBB 1993-2011, eigen berekeningen 